\title{
Black Activism: John Updike
}

\author{
Dr. Suchitra Vashisth
}

\author{
Assistant Professor, DIT University, Dehradun, Uttarakhand, India
}

A major novelist, a short story writer, and a poet, John Updike is a distinguished writer of American literature. His work has received international criminal acclaim. As a literary artist, he has given us most powerful expression of the American racist society. His writing is personal, not subjective. It pleases his busy imagination, his sense of humor and his understanding of contradictions within every segment of human display.

Talented, innovative, distinctly not an outsider, Updike is a writer in the post-war inhabited style, a writer who allied himself with families, townships, churches, citizen's committees. He became a novelists of "society in the fifties, the age of post-war plenty and unconcealed domesticity for both sexes. Domesticity is a prevailing subject of his novels and so is the unavailing move violently against it, as is in his famed novel, Rabbit Run. But there is, in even the clear emotions of Rabbit Run and in the filial compassion of The Centaur, a kind of radiant actio lessness, a completely cerebral tone. $\mathrm{He}$ is an exceptionally competent spectator of the social order and its ethnicity and way of life. He has dealt with the postwar culture and its customs and traditions. He has dealt with the post-war society and its astonishing transaction of classes, back-grounds and items of social information. He likes to put President Buchanan (ancient history) and President Kennedy (the sixties) to show that they are genuine landmarks. There is no thrash about with American society; its character is fixed.

For Updike, everything has been probable. He knows his way around, in every sense, without being apparent about it. His actual subject - the lifeless hand of "society", the fixity of institutions - has gone hand in hand with the only idea of free will as the individual's acknowledgment of God. This is a period when, Updike says, "God has killed the churches". If poise is gift, Updike is a whiz kid. If to be "cool" is not just a social elegance but consciousness infinite, Updike is the best of his cool humankind.

Updike has asserted that he agrees with "Freud's view about the centrality of sex", and that his hard work is heading for presenting the "truth about sex". One must strain however that Updike's intentions are the precisely contradictory of pornographic; he takes sex critically and believes that art imposes values upon it portrayal. At its best and least precise, Updike's dealing of sex will partake in the same dialectical visualization of man's "mixed" human form, a idea tempered by wit and significant with metaphor, that his other themes will replicate. The secrecy of sexuality is ever that a mystery; and yet the sexual meet not only involves the unexplained "Other" but is revelatory of the mystery of the identity as well. In his fiction, Updike makes a facet learning of sex in its social and psychological associations. Updike's characters consequently take on sex as a means to set up contacts with other. This way they rejuvenate themselves and look for love and elegance.

Hence on Updike's fiction sex also acts as a source of individual freedom and a mode of selfactualization. His characters adopt adultery as a means to realize their identity, confirm their existence, share human warmth, and renew their creative potentialities. Lawrence and Updike seem to differ in their approaches to sex; the former treats sex as a religion in itself; and the latter makes contingent upon belief in the supernatural. Updike holds the sex can redeem our social ailments only when we have belief in God. Otherwise, it merely satisfies our animal instincts and leads us nowhere. This has been his central preoccupation since his novel. In Updike's fiction female characters are generally the most keenly observed, the most perspicacious, practical, and mature; they are given the best lines, endowed with the most genuine wit, and privy to the most realistic opinions and sensations about life's mysteries. Yet the overarching sexual theme itself always betrays a masculine viewpoint. The narrowness and particularity of Updike's sexual world, however, do generate critical difficulties. Updike's world is usually devoid of any responsive male in it, save for the central character and occasionally a father and son. Among the white writers John Updike and William Styron are mainly concerned with the wave of social paranoia. They have delineated the problem of racism between the whites and the blacks in the contemporary society. Late in the fall of 1971, Updike published Rabbit Redux, his sequel to Rabbit Run. With familiar characters, this novel is less a sequel to the earlier one than a development of the historical and social concerns apparent in Updike's writings from Couples onward. This older Rabbit is, in many ways, a man displaced by cultural change and made passive and inarticulate by onrushing Political and social currents. Updike has said that he decided to write the sequel; If Rabbit Run was a novel of the 1950's, Rabbit Redux is for the 1960's. If in the 
first novel we found a Rabbit as a frustrated American Adam anxious to discover new frontiers, in this novel we find him not only an American Adam fallen, unredeemed but even immobilized. His Eden is attached by the blacks.

The title of Rabbit Redux means "Rabbit led back". Harry Angstrom is now thirty six. He has grown politically conservative. He lives with his wife, Janice, and thirteen-year old son, Nelson, in Penn Villas, the new housing development on the outskirts of Brewer, Pennsylvania. His life is bounded by his Job as a linotype at the Verity Press and his boring routine at home. His occupation is a passé and like himself, he is a victim of technological change. A linotypes' concern rests entirely with space and with the contrast between black and white, as well as with language. We are told that "All around him Rabbit hears language collapsing." He moves only when he takes the bus or drives in to Brewer for a tasteless dinner with Janice and Nelson. Finding him in the first yard, c white American liberalism leaves every one panicky and insecure, women's liberation movement brings disaster to the material relationships, protests against the Vietnam War divide the whole American community into factions. Besides, the rise of an activist young generation, totally unaware of the old religious and social values and completely incapable of creating new, adds more confusion to chaos. Therefore, America's upward movement into the empty space coincides with her downward movement into moral and spiritual void. In Rabbit Redux, Updike creates the atmosphere of social anarchy in a truly realistic manner through TV news. Updike sets all these adverse social forces of the day active in Harry's house to consider the burning problem: how does one survive us an individual in to-day's America. Harry is bewildered by the changes that loom beyond his control. The moon space flight alters his universe, the blacks alter his society and the adultery in society alters his home. While Janice dreams of her lover, "the papers and television are full of the colored riots in New York, snipers wounding innocent firemen, simple men on the street, what is the coming to? The astronauts are nearing the moon's gravitational influence." 1 His home in Penn Villas represents his own isolation and suspension in a void. Jill, a rich-eighteen-year old runaway, who comes to live with him in house, rightly says to him: "You carry an old God with you, and angry old patriotism. And now an old wife.... you raced to the conclusion that everything is nothing, that zero is the real answer."2

John Updike's Rabbit Redux contains the story of the black revolution in America in the nineteen sixties. Updike reveals, through the speeches of Skeeter, black revolutionary, social injustices with the blacks in
American society Richard Locke points out that the wide range of tones and rhythms in black speech has never been so well produced in contemporary white writing."3 Skeeter who is the representative of the black people delivers nightly sermons on Afro-American history. Commencing on this character, Locke says, "Thus black is portrayed with enormous sympathy and force and is anything but an allegorical cut-oput."

In absence of his wife, Harry meets Jill Pendleton, an all-night bar caterer to the blacks, Janice moves out and Jill moves in, and Harry is yanked into new worlds and strange sex. Harry offers Jill refuge from the netherworld of drugs and hustlers. Dressed in soiled white, and still young enough to look happy when handed a lemonade, Jill is more sexually experienced than Harry, ready to sleep with him Just to pay for the hamburger he buys her. Jill adopts the role of mistress and homemaker while Harry plays for lover and provider. She is pliable, gentle, loving and doomed. Harry admits that she has renewed his taste for living, but he does not know how to respond to people like Jill who apparently feels no fear. She makes Harry realize that he has withdrawn from life and love because he does not think of himself. She makes him sexually "arrived" or "landed" especially after his long denial. At the beginning of the novel we are told that he "hates" sex. We hear him reflect that "Sex ages us, Priests are boyish, spinsters stay black-haired until fifty, We others, the demon rots us out." 5 We expect a change after his union with Jill but he remains unchanged by sexual activity and still views sex as a grim business. He tells Janice near the end of the novel: "But all this fucking everybody fucking, I'd not know, it just makes me sad. It's what makes everything so hard to run.... There must be something else."

Like a good Samaritan and the "Statue of liberty" Harry brings Skeeter to his house for his protection. Skeeter is a young black militant and Vietnam Veteran. Harry learns from about Afro-American history, the Vietnam War, and the treatment of the blacks by the law and the corruption by the whites. Under the chairmanship of Skeeter they have evening sessions together and discuss different sorts of problems like American history, Vietnam War, American Politics, racial problem in America, Christianity, and America's future from a black point of view. During these seminars they seldom offer any viable solutions to these problems. Their debates hardly rise above the level of a confrontation between the liberalism of the white Americans and the radicalism of the black Americans. Nevertheless these discussions present a clear picture of the characters of Jill, Harry, and Skeeter. Harry handles the whole situation very tactfully. Rabbit sometimes agrees with Skeeter's radical views and at other times he disagrees very mildly. Actually, Harry 
agrees with Skeeter on some issues in order to disagree with him emphatically on some other vital issues. This way Harry tactfully keeps Skeeter from losing his temper more frequently during their conversations. For example, when Skeeter tells Harry about the White American's past cruelties towards the blacks. Harry says, "I believe all of it" But, when Skeeter talks further on this issue Harry retorts saying, "Trouble with your line".... 'It's pure selfpity. The real question is, where do we go from here? This is the freest country around; make it if you can, if you can't, die gracefully. But, Jesus, stop begging for a free ride."7 Skeeter assumes the role of vitalizer. He is the angry young black whose hatred and militancy against the whites have provided the necessary system of values and emotional energy to invest in these values. His hostility lends importance and identity to the features of American racist society. Listening to Skeeter's bitter foul mouthed descriptions of the whites and race relations. Rabbit slowly realizes: "There seems to be not only a history but a theology behind his anger." ${ }^{\text {,8 }}$ Later during the long talks in Rabbit's living room, it becomes clear that history is Skeeter's theology. In extended monologues, he recounts his view of American history. At the conclusion of one of these lectures recounting black humiliation and suffering Skeeter asks: "Do you believe any of this? I believe all of this." Rabbit calmly replies: "Do you believe? Do you believe? I'm so mad just telling this if I had a knife right now I'd pope it in your throat and watch that milk fair blood come out and would love, it, oh, would I love it."9

One day when Nelson and Rabbit are away from the house, a peeping Tom sees Jill and Skeeter in sexual congress, and later the two white men set Rabbits house on fire. Skeeter informs Harry on the phone and he runs away leaving Jill sleeping inside. Harry returns to find almost the whole of his house burnt up and Jill dead inside. Jill dies a sacrificial figure. Skeeter does not save her because she is a white girl. Thus Jill's death in the fire is due to the culture pollution in American society, due to racist feelings of Skeeter. Though Skeeter enjoys sex with Jill, a white girl, he hates her as a white community. He is a conservative black radical who wants to take revenge on the white Americans for their discrimination against the blacks. After the fire episode and Jill's death, Harry teaches about the situation in the American Society, from Jill about Janice's genuine need for rebellion, and from his encounters with Stavros, a black, that his antagonist probably has more to offer his wife than himself. He takes advantage of his knowledge and gets ready to face the reality in its true perspective. Harry is dismissed from his service. In utter depression as jobless, homeless and wifeless he moves to his parents' house. His sister, Mim, comes back to her parents' house and, like a douse ex machine, begins to straighten out the tangled relationships. She meets Janice's lover and develops an affair with him. Janice leaves him and joins back Rabbit. The novel closes with Harry and Janice going to the Safe Haven Motel where they sleep in apparent contentment. Both are Redux. Updike's final words suggest the equilibrium achieved, the truce declared: "He, she, sleeps O.K.?"10

Updike here interprets American life in the Sixties and the novel becomes a model of modern-day American history. The major characteristics are representatives without losing their credibility as individuals and the situation remains convincing while they reflect the historical event. Richard Locke comments that in Rabbit Redux, Updike “pulls against the 1960s and defends his hero's new commitment to civilization, his longing for social and personal continuity where both are hard to come, by"11 and loss of human values, the black revolt, the despair of American youth, the war in Vietnam, and the sexual freedom of women are brilliantly portrayed in the novel.

In the beginning of the novel, John Updike shows how the black people in American racist society were discriminated and hated. Harry feels insulted even by talking to August Buchman, a black co-worker. John Updike describes this as follows: "Distaste, and excitement contend in Harry, he feels tall and pale beside Buchman. Tailing to Negroes make him feel itchy. Up behind the eye balls, may be because their look so semiliquid and yellow in the white and sore."12 Racial hatred against the blacks has been expressed through Harry and his father. Earl Angstrom is blazed against them and holds that they have spoiled white society. He regards American Negroes as "the lowest of the low".

This biased attitude towards the blacks caused the black revolution, and angry blacks forced upon white consciousness the bitter knowledge of their collective pain and degradation as in Rabbit Redux. Skeeter grows violent while telling Harry the history of black slavery. The white people did not like the Negroes' deformed body, their colour, and their ways of behaviors. Owing to this reason, race relations between the whites and the blacks were very bitter, and in the Sixties the black revolution was assuming militant form. Updike throws luminosity on the nervous state of affairs of the race relations in the opening of the novel: "The bus has too many Negroes ...they never hurt you, just looked; but now they're noister ..... Sad business, being a Negro man, always underpaid .... They are a strange race. Not only their skins but the way they're put together loose - jointed like lions, strange about the head, as their thoughts are a different shape and come out twisted even when they mean no menace."13 
The black people were victims of poverty, exploitation physical torture and disrespect in the white racist society. They did the whole labour at agricultural farms and in the houses, and the white people enjoyed the fruits of their labour. The blacks were whipped, lynched and even starved. Sometimes they were put to so much hard labour that they died "working those cotton swamps" Skeeter verifies the above fact:

"So what did the South do? They said ape and lynched and whipped and indignant the black man of what pennies he had and thanked their white Jesus, they didn't have to supply him anymore. And what did the North do? It cooped out. It pulled out. It had put on all the power for the war and now it was wading into the major, happiest much of voracity and embed and misuse and toxic waste and slum-building and Indian-killing this deprived whore of a planet has ever been saddled with, right'..... The Southern assholes got together with the North assholes and said, Let's do a deal. What's all this about democratic system, let's have here a dollor-cracy, why'd we ever think about, liberated versus slave? Wealth versus struggle, that's where it's at, right? ..... you bolt your black labor and we'll screw our immigrant honky and Mongolian idiot labour ..... So let's all sing America the Beautiful, right? North and West, robber barons and slums. Down South, one big nigger basbecue."14

Even the law did not come to the help and support of the blacks. The Amendments made in their favour remained forceless due to the strong, opposition by the white supremacy. The segregation, exploitation and deprivation of voting still continued.

The black people were not regarded as human beings by white community. They were sold like animals. They were "property" to the white people. The law, though in their favour, could not check the purchase and sale of the Negroes. John Updike has used American history as a material for writing this novel. It is through Skeeter's speeches that we come across the history of the black people, their arrival to the United States, their sale as slaves, their oppression and exploitation by the white people in America, the hard labour they were put to, etc. Skeeter asks Jill to read his old speech from a book. Jill reads:

"Think....of the nature's deed, done continually and afresh God shall hear the voice of your brother's blood, long crying from the ground; His Justice asks you even now, 'America where is the brother? 'This is the answer which America must give: 'Lo, he is there in the rice-swamps of the South, in her firledsteemping with cotton and the luxuriant cane. He was weak and I seized him; naked and I bound him, ignorant, poor and savage, and I ove-mastered him. I laid on his feebler shoulders my grievous yoke. I have chained him with fetters; beat him with my whip. Other tyrants have dominion over him, but my finger was on his human flesh. I am fed up with his toll, fat voluptuous on his sweat, and tears and blood. It stole the father, stole also the sons, and set them to toil; his wife and daughters are a pleasant spoil to me. Behold the children also of the servant and his hand maidens-sons swarthier than their sire.' Askest thou for the African? I have made him a beast. Lo, there thou hast what is thine." 15

The black people were required to commence anti-slavery campaigning in America. The States could not ameliorate the position of the blacks, and even Church was powerless to provide any help. The entire communal system was inhuman. Skeeter desires the whole system be cracked.

"If the state cannot survive the anti-slavery agitation, then let the state, perish. If the church must be shed down by the under pressure of Humanity, than let the Church collapse, and its wreckage be scattered to the four winds of heaven, never more to annoyance the earth. If the American Union cannot be maintained except by immolating-what's that? ..... If the system, even if it works for most people, has to oppress some of the people, then the whole system should be destroyed."16

Skeeter, the black militant, may be foul-mouthed, temperamental, unreasonable and even ludicrous, but compared to the dried-up, emotionally frozen, morally enervated whites, he has the vitality and system of values necessary to human action and survival. He calls himself Jesus: "Hay, I'm the real Jesus. I am the blacks Jesus.... ${ }^{17}$ In the novel's terms, it is true. He is the merely one with values profound enough and a image of America strong enough to be a priest and life-giver Skeeter rages and weeps and calls upon God. Updike at one point suggests that deprivation has preserved the minority group's energies. Harry tells Jill that everything is 'dead' for her because it was given to her 'fear'. That's what makes us poor bastards run, "he says”, you don't know what fear is, do you, poor baby? That's why you're so dead." 18

Skeeter is redeemer figure like Christ. As a black radical, he wants to redeem blacks. As we have already discussed above, he labels himself a Christ, that Updike's imagery reinforces this. Skeeter's glasses are "to as haloes" of light. Jill warns that the police will "crucify" Skeeter if they catch him. When Skeeter undresses, Harry has never seen such a chest "except on crucifix". At the end Harry takes Skeeter to a place called Galilee where Skeeter spits in Harry's hand, an ironic blessing-an echo of the spit which signifies "America" in the baseball game. The history of black people in America and their sufferings have convinced him that he 
has to be something for the blacks. He becomes an American-history buff. Skeeter wants to take revenge on the white Americans for their discrimination against the blacks. He uses the language of unreason and condemns Harry's nationalism and religion. "Your white God is queer than the Queen of spades. He sucks off the sacred spirit and makes his son watch. Hay, chuck. Another thing. Ain't no Jesus. He was a faggot crook, right?" ${ }^{19} \mathrm{He}$ acts as a self-styled black Jesus aspiring to bring liberty to the blacks though disorder and violence: "The old Jesus brought a sword, right? The new Jesus will also bring a sword. He will be a living flame of love. Chaos is God's body. Order is the Devil's chains"20 Skeeter beats Jill, scares Nelson and terrorizes Harry. He does not take Jill out after two white men set Harry's house on fire. When Harry asks him, "Why didn't you get her out?" Skeeter replies, "Hell, man, there was heat, right? I though lynching time had come. I didn't know there wasn't twelve hundred crackers out there, I was in no shape to take care of some whitey woman, let whitey take care of his own."

The remarkable thing which is depicted here in this novel is a white failure of nerves or at least a flagging sense of white identity in the face of black assertiveness. Harry and Jill, both rudderless white people, are caught in the powerful undertow of the black man's vehement selfaffirmation. This is true when Harry's submission to Skeeter is reflected in his remark, "I believe all of it." Harry support Skeeter and helps him in escaping when the house is burned. Though Harry's loyalty to the idea of America does not change, now, after Skeeter's bitter lectures, he wonders what America has been: "Rabbit is deeply shaken by his extended encounter with Skeeter, literally and figuratively burned by it, but he remains more or less what he was," 22 This shows the bigotry and social hypocrisy of white American's genuinely believing in social equality. The novel becomes a real portrait of racism and of black-white confrontation based on contemporary race relations, and incarnates more specifically the relations between Harry and Skeeter and between Skeeter and Jill. Through Skeeter Updike succeeds in depicting the oppressed and class-ridden society. Skeeter's schizophrenia is manifested in his fragmented personality, social avenger and redeemer, minor criminal and seducer. This schizophrenia strain is national and is particularly virulent is Skeeter. Because he has been subjected to so many roles; as black man in white society, as soldier in a controversial war. Robert Detweiler observes, "The depiction of an amoral, crazy Negro offered in the context of the volatile contemporary racial situation in the most audacious yet of Updike's experiments with borrowed voices...... Skeeter is too powerful for the otherwise cast of the novel."23
John Updike has depicted the response to racism in the novel through realistic characters, through racial hatred between the whites and the blacks. Jill and Skeeter are the true characters of the nineteen sixties. Jill is the nineteen sixties student rebel and Skeeter a black militant. The blacks in the novel have been described very physically hair, arms, legs, mouths, smells and so on. In the bar, Harry sees them as "panthers", Skeeter represents an attack of black militancy on the consciousness of the white Americans. Free sex by the blacks is a symbol of individual freedom, a realization of self-identity, confirmation of their existence and potency. The burning of Harry's house symbolizes the burning of the house of white supremacy in the American society.

\section{REFERENCES}

[1] Rabbit Redux; p.57.

[2] Ibid, p.228.

[3] David Thorburn and Howard Eilandceds John Updike: A Collection of Critical Essays (New Jersey: Prentice Hall, 1979) p.37.

[4] Ibid, p.38.

[5] Rabbit Redux, p.71.

[6] Ibid, pp.397-398.

[7] Rabbit Redux, p.203.

[8] Ibid, p.112.

[9] Ibid, p.207.

[10] John Updike, Rabbit Redux (NewYork: Knopf, 1971) p.407.

[11] John Updike: A Collection of Critical Essays,p.36.

[12] Rabbit Redux, p.92.

[13] Ibid, pp.12-13.

[14] Rabbit Redux, p.232.

[15] Rabbit Redux, p.243.

[16] Ibid, pp.244-245.

[17] Ibid, p.210.

[18] Rabbit Redux, p.152.

[19] Ibid, p.183.

[20] Ibid, p.237.

[21] Ibid, p.287.

[22] John Updike: A Collection of Critical Essays, p.47.

[23] Robert Detweiler, John Updike (NewYork: Twagne; 1972) p.163. 